\title{
INNOVATION PROJECTS ASSOCIATED TO THE COMPETENCE OF INNOVATION, CREATIVITY AND ENTREPRENEURSHIP IN THE UNIVERSITAT POLITÈCNICA DE VALĖNCIA
}

\author{
M.M.E. Alemany ${ }^{1}$, L. Cuenca ${ }^{2}$, A. Boza ${ }^{2}$, M. Fernandez-Diego², L. Ruiz ${ }^{2}$, \\ F. Alarcón ${ }^{1}$, M.L. Gordo ${ }^{2}$ \\ ${ }^{1}$ School of Industrial Engineering. Universitat Politècnica de València (SPAIN) \\ ${ }^{2}$ School of Computer Science Engineering. Universitat Politècnica de València (SPAIN)
}

\begin{abstract}
This paper describes the Innovation and educational improvement projects developed in the Universitat Politècnica de Valencia, oriented to the competence of innovation, creativity and entrepreneurship. These projects have been developed by a team of lecturers from different fields of knowledge. The projects have been applied and validated on two subjects of the School of Computer Science Engineering and two subject of the School of Industrial Engineering in the Universitat Politècnica de Valencia
\end{abstract}

Keywords: Innovation, technology, educational improvement projects.

\section{INTRODUCTION}

In the report of Bucharest, April 2012, Ministers identified three key priorities - mobility, employability and quality, and emphasized the importance of higher education for Europe's ability to deal with the economic crisis and to contribute to growth and employment. The UPV degrees have a structure based on modules and subjects. Modules include the list of subjects and the number of credits that includes each one of them. Transversal competences UPV seek to synthesize the competence profile to be acquired by the students, ensuring the reference framework of some degrees with regulations or specific recommendations. A total of 13 transversal competencies have been defined. 1understanding and integration; 2-implementation of practical thinking; 3-analysis and problems solving; 4-innovation, creativity and entrepreneurship; 5-design and project; 6-team work and leadership; 7-liability ethical and professional; 8-effective communication; 9-critical thinking; 10knowledge of contemporary problems; 11-lifelong learning; 12-planning and time management; 13specific instruments.

Evidence of competence acquisition must be reflected in the design of new curricula. It is necessary to define:

1 Guidelines for assessment: the assessment system must ensure a continuous assessment of the learning outcomes achieved. A goal is transform the teaching-learning process to make the student main protagonist and, in this regard, it is necessary to orientate schedules and teaching methodologies of subjects placing them in the learning process of students. The key is to consider the program of each course as a set of activities that ensure the student's learning and introduce the mechanisms needed to motivate the student to do it.

2 Guidelines for the follow-up of the activities. The activities should be designed in such way that engage students to active participation in class with the purpose of promoting their progress.

3 Guidelines for programs. The use of active methodologies where the student should participate, individual or working group and problems, tests at the end of the lab sessions, one - minute paper, evaluation between peers and self-assessment activities, etc.

Competence-based learning requires an effort that it does not only depend on strategies of teaching, but also to know select and apply adequate resources for its achievement.

On this basis we propose resources aimed at the development of competences, thus helping a proper recovery and reuse these resources [1]. To develop the abilities and skills needed in each competence, it is very important to the teacher to have access to adequate teaching resources which can be adapted to the different educational needs of the students. 
The strategic plan of the UPV includes a project for master and bachelor degree, with the strategic challenge of being a leader in high quality teaching and training, oriented to the needs of the society. This marked among other objectives and plans: to Incorporate competencies into all curricula (degrees and master's degrees), and increase the level of internationalization of the degrees.

Next figure shows the three projects developed by our team AEGECATE (Experimental Learning in management for technical degrees) and their association to the strategic plan of the UPV.

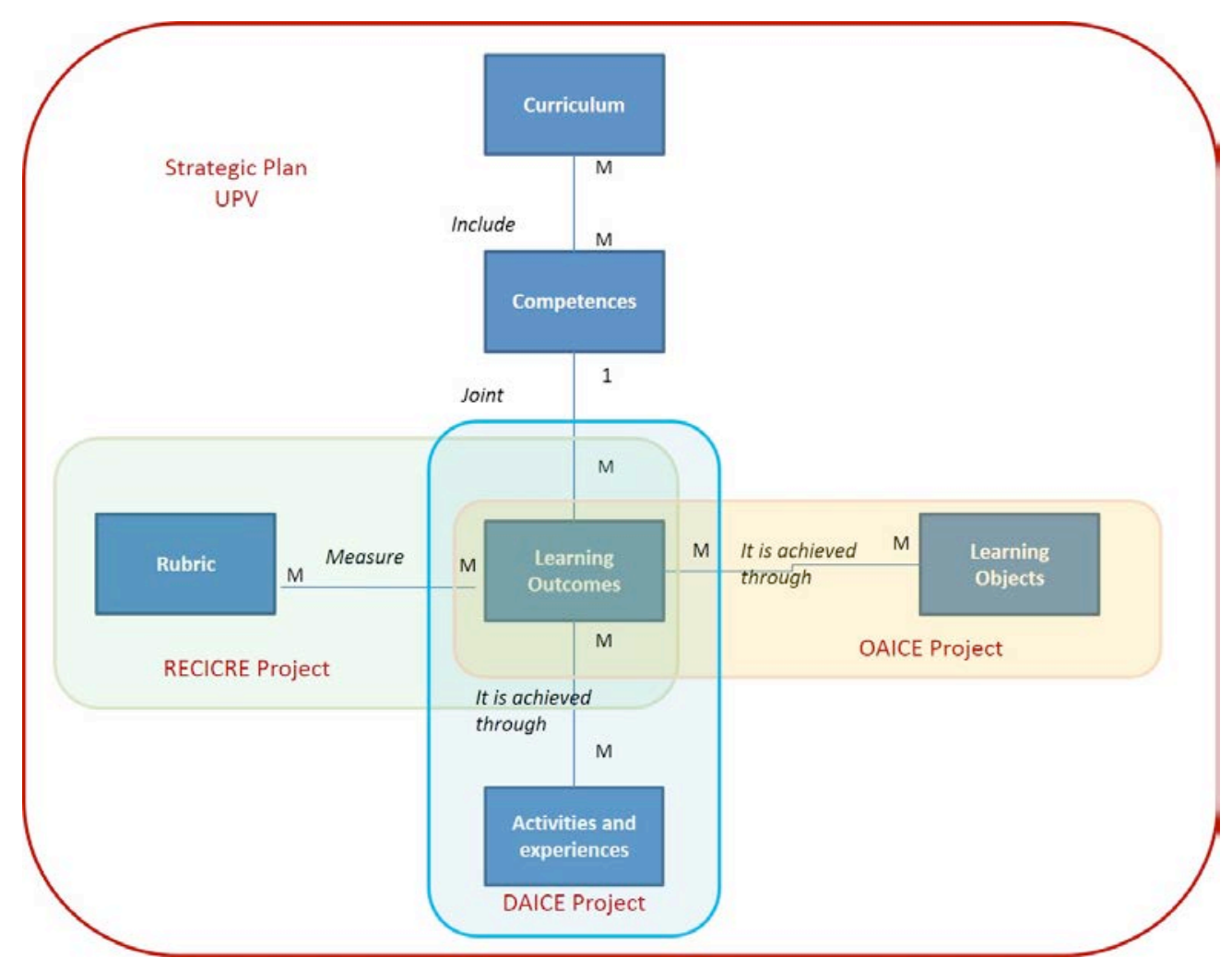

Figure 1 PIME Projects developed by AEGECATE Team according to the strategic plan of UPV

\section{RUBRICS FOR THE ASSESSMENT OF INNOVATION, CREATIVITY AND ENTERPRENERUSHIP COMPETENCE (RECICRE PROJECT).}

\subsection{Objective}

The objective of this project was to develop a method for measuring the innovation competences in higher education in bachelor and master degrees, by the definition of different levels of mastery and different perspectives that should be considered in the innovation, creativity and entrepreneurship competence.

\subsection{Method}

Learning outcomes have been identified for bachelor degree and master degree and grouped under a general aim. Once the final list was obtained, the learning objectives were classified according to [2] to obtain a structured list according to the characteristics of innovation. [2] estates that leaders must be able to think creatively while taking initiative and calculated risks.

Effective leaders have a vision beyond the immediate work of the group. This involves exploring and integrating diverse perspectives and recognizing unexpected opportunities. The perspectives that should be considered in the innovation competence are creativity, entrepreneurship, integrating perspectives, forecast and change management.

Once the learning objectives associated to innovation competence have been identified and classified, we are able to develop an assessment method for measuring the achievement of these objectives and therefore the acquisition of the competence [3]. 


\subsection{Results}

The objective of this proposal was the measurement of the innovation competencies in higher education by introducing different levels of mastery. As noted in the introduction section, following a standard process improves the fairness when evaluating.

In this sense, rubrics can be considered a good assessment tool. A related concept to both structure and functionality is the maturity model. The maturity model provides a rubric for determining process maturity levels as well as a roadmap for achieving the optimal level of high-quality operations. Maturity is defined as a measure to evaluate the capabilities of an organisation in regards to a certain discipline. As a rubric, the Maturity Model identifies critical factors with progressions across the levels of maturity. In order to develop the rubric as an assessment tool and its similarity to established maturity models, we followed the methodology defined by [4].

An extended rubric according the whole list of learning outcomes can be consulted in, [5, 6 and 7]. This extended list of learning outcomes have been refined in order to facilitate the assessment process and an abridged version can be found in [8].

\section{LEARNING OBJECTS FOR THE INNOVATION, CREATIVITY AND ENTREPRENEURSHIP COMPETENCE (OAICE PROJECT).}

\subsection{Objective}

To acquire competences, certain learning outcomes are established, which must be met. The competency-based learning requires an effort that depends not only on teaching strategies, but also to know how to select and apply appropriate resources for their achievement. On this basis, resources should be proposed aimed at developing skills, helping to adequate recovery and reuse of these resources One way to transmit knowledge to achieve these learning outcomes is through learning objects. The objective of this project was on one hand, to clarify the learning object definition and its classification to define the main elements associated to the learning objects, such as metadata, repository and different methodologies, and on the other hand to propose learning objects associated to the competence.

\subsection{Method}

In existing literature various researchers have attempted to define a Learning Object. However, a review of this literature shows a lack of consensus in the terminology used as well as in the dimensions addressed during its definition. In this section, different dimensions to define a learning object are proposed based on the literature review made. These dimensions have allowed to carry out a structured analysis of the different learning object definitions. A synthesis of the results obtained is presented at [9].

\subsection{Results}

From the study of the different learning object definitions in the literature and their integration, it can be concluded that some of the following dimensions are addressed:

1 What is? Through this dimension authors identify learning objects with existing teaching elements

2 How it is supported? The material and technology support is covered through this dimension.

3 How is it? Relevant properties of learning objects are described in this dimension.

4 How it is used? It is interesting to know for what, when and where the use of learning objects is appropriated.

The extended results of this part of the project can be found in $[9,10]$. The learning object defined will published into the RiuNet platform. RiuNet is the institutional repository of the Politechnical University of Valencia - UPV, managed by the Library, whose objective is to offer Internet access for university's scientific, academic and corporate university in order to increase their visibility and make it accessible [11]. 


\section{ACTIVITIES AND EXPERIENCIES DESIGN FOR THE INNOVATION, CREATIVITY AND ENTREPRENEURSHIP COMPETENCE (DAICE PROJECT).}

\subsection{Objective}

In the current project, the objective is the design of activities to complement the learning objects, which will be developed in the classroom with the purpose of promoting the acquisition of the learning outcomes associated with the competence under review. This aspect is widely demanded by the teachers, which do not have proposals to develop in their subjects.

\subsection{Method}

The proposed methodology covers the following phases:

1 Review and analysis the current activities or experiences: It will conduct the review of different documentary sources and experiences of the team members what will be the starting point for new designs.

2 Review learning outcomes and classify them by activities. This revision allows to assign learning outcomes addressed in each activity.

3 Detect needs: this activity review if all the learning outcomes have been covered with the proposed activities with the objective of identifying gaps which promote the proposal of new activities.

4 Design Activities: with the objective of ensuring a successful learning process, the activities will include not only content but that also guides to the process of student learning. The design must include different elements, such as, learning outcomes that are intended to achieve, degree, level and subject, topics to be tackled, name, type of activity, development of activity, evaluation, time and material used.

5 Implementation: it will be deployed on different subjects during following courses.

\subsection{Expected Results}

This is an ongoing project, therefore the results obtained are still uncompleted. For each phase of the methodology, one or several results will be obtained.

\begin{tabular}{|c|l|}
\hline $\begin{array}{c}\text { Existing activity } \\
\text { analysis }\end{array}$ & $\begin{array}{l}\text { List of existing activities for master degree } \\
\text { List of existing activities for bachelor degree }\end{array}$ \\
\hline $\begin{array}{c}\text { Classification of LO's } \\
\text { per activity }\end{array}$ & $\begin{array}{l}\text { List of LO achieved for each activity in master degree } \\
\text { List of LO achieved for each activity in bachelor degree }\end{array}$ \\
\hline FIT and GAP analysis & $\begin{array}{l}\text { In this activity it is analyzed if the LO have been covered } \\
\text { with the proposed activities (FIT), or not (GAS). }\end{array}$ \\
\hline Design of activities & Template with the information associated to the activity \\
\hline
\end{tabular}

Example of activity can be found in [12]

\section{CONCLUSION}

This paper puts forward the projects developed by the AEGECATE team in the UPV. These projects contribute to the strategic plan of the UPV to incorporate competencies into all curricula (degrees and master's degrees). The projects have demonstrated the usefulness to the teacher by helping the teacher in the difficult context of the competence-based-learning, and the helpfulness to the student for better learning outcomes. They help the students to engage positively in developing their competences.

The rubric help to assess the competence acquisition level and it is important because student raise awareness of the need to develop their competences; it can support a transformation in teaching 
culture and practice because rubric can also be used as a tool to develop new activities, and finally it help to recognize the competences acquired or developed.

\section{REFERENCES}

[1] Morales E., García F., Campos R., Astroza C. Desarrollo de competencias a través de objetos de aprendizaje. RED. Revista de Educación a Distancia, núm. 36, marzo, 2013, pp. 1-19

[2] Bapat et al., 2014 Technical Report. http://www.chsbs.cmich.edu/leader_model/assess.htm

[3] Boza A., L. Cuenca, M. Fernández-Diego, L. Ruiz, M.L. Gordo, F. Alarcón, M.M.E. Alemany, R. Poler (2014) INNOVATION, CREATIVITY AND ENTREPRENEURSHIP COMPETENCE IN HIGHER EDUCATION. LEARNING OBJECTIVES AND MEASUREMENT, ICERI2014 Proceedings, pp. 405-411.

[4] Cuenca L., Boza A., Alemany MME, Trienekens J.. (2013) Structural elements of coordination mechanisms in collaborative planning processes and their assessment through maturity models: Application to a ceramic tile company. Computers in Industry 64 (2013) 898-911

[5] Cuenca L., M Fernández-Diego, ML Gordo, L Ruiz, Alemany MME., Ortiz A. (2015) Measuring Competencies in Higher Education. The Case of Innovation Competence. Sustainable Learning in Higher Education, Innovation, Technology, and Knowledge Management. Springer, 2015, pp 131-142

[6] Cuenca L., Boza A., Fernández-Diego M., Ruiz L., Gordo ML., Alarcón F., Poler R., Alemany MME. (2015) Rubric to assess the competence of innovation, creativity and entrepreneurship in bachelor degree. XXI International Conference on Industrial Engineering and Operations Management Aveiro (Portugal) from July 6th-8th, 2015.

[7] Cuenca L., Boza A., Fernández-Diego M., Ruiz L., Gordo ML., Alarcón F., Poler R., Alemany MME. (2015) Rúbrica para la Evaluación de la Competencia Innovación, Creatividad y Emprendimiento en Máster. Congreso In-Red 2015. Universitat Politècnica de València. Doi: http://dx.doi.org/10.4995/INRED2015.2015.1610

[8] Cuenca L., P. Bonet, A. Boza, P. Fuentes, N. Lajara-Camilleri, J.A. María-García, M. PerisOrtiz, L. Ruiz (2015) INNOVATION, CREATIVITY AND ENTREPRENEURSHIP LEARNING OUTCOMES IN HIGHER EDUCATION, ICERI2015 Proceedings, pp. 3910-3915.

[9] Alarcón F., M.M.E. Alemany, A. Boza, L. Cuenca, M.L. Gordo, M. Fernández-Diego, L. Ruiz (2015) LEARNING OBJECT. DEFINITION AND CLASSIFICATION, EDULEARN15 Proceedings, pp. 4479-4488.

[10] Fernández-Diego M. , M.L. Gordo, A. Boza, L. Cuenca, L. Ruiz, M.M.E. Alemany, F. Alarcón (2015) METADATA, REPOSITORY AND METHODOLOGY IN LEARNING OBJECTS, EDULEARN15 Proceedings, pp. 4755-4761.

[11] RiuNet Institutional Repository of the Politechnical University of Valencia https://riunet.upv.es/

[12] Ruiz L., Mariluz Gordo, Marta Fernández-Diego, Andres Boza, Llanos Cuenca, Faustino Alarcón y María Del Mar Alemany-Díaz (2015) Implementación de actividades de aprendizaje y evaluación para el desarrollo de competencias genéricas: un caso práctico de aplicación de técnicas de Pensamiento de Diseño, y evaluación mediante rúbricas, de las competencias de Creatividad, Innovación y Emprendimiento. Congreso In-Red 2015. Universitat Politècnica de València Doi: http://dx.doi.org/10.4995/INRED2015.2015.1639 